\title{
Wageningen Social Innovation Approach Een uitnodiging tot participatie
}

\author{
3. \\ $7 \times$
}

$+2 x+2+1$

(1)

Clat

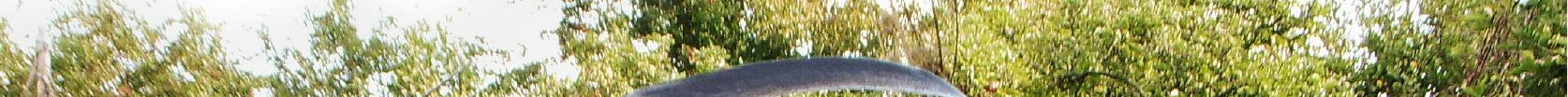

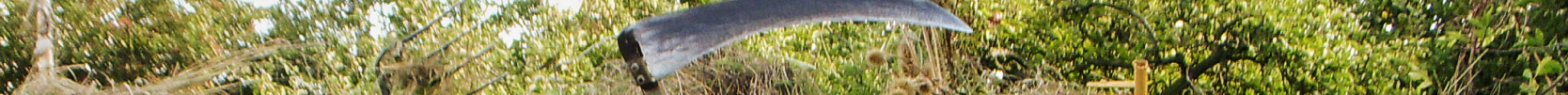

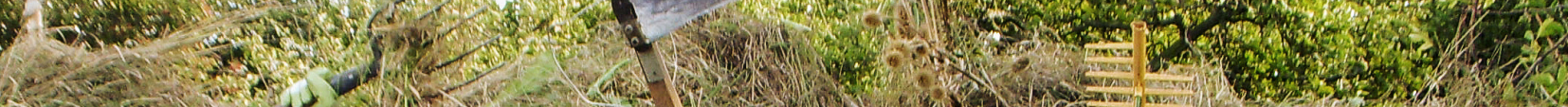

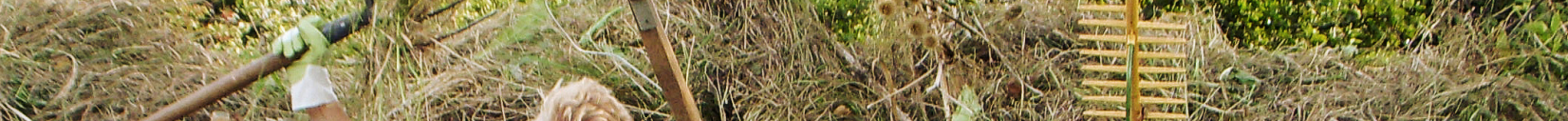

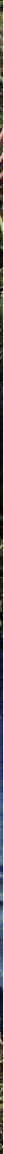

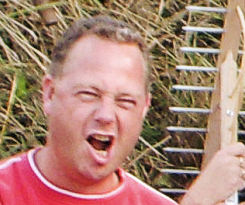




\title{
Wageningen Social Innovation Approach
}

\section{Een uitnodiging tot participatie}

Wageningen Social Innovation Approach

Een uitnodiging tot participatie

Roel During \& Hans Dagevos

Wageningen University and Research, December 2018

Dit essay komt voort uit het KB programma Sociale Innovatie voor Waardecreatie.

Met dank aan Nina de Roo, Jan Brouwers, Jeroen Kruit, Volkert Beekman, voor

commentaren en suggesties op conceptteksten.

\author{
Roel During en Hans Dagevos
}

DOI: https://doi.org/10.18174/466716

Ontwerp: www.studiods.nl

Foto cover: Marieke Muilwijk

$\begin{array}{r}\text { WAGENINGEN } \\ - \text { UNIVERSITY \& RESEARCH } \\ \hline\end{array}$ 


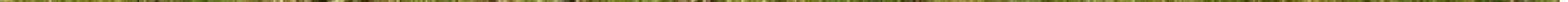

$\mathrm{I}$

n 2015, ten tijde van het vorige strategisch plan van Wageningen University \& Research (WUR), is sociale innovatie als belangrijk thema benoemd. Een thema dat vervolgens is belegd in het programma 'Sociale Innovatie voor Waardecreatie' (SI4VC). In dit programma zijn vanuit theorie en praktijk verkenningen uitgevoerd naar maatschappelijke veranderingen die worden aangeduid als sociale innovatie, en er is gekeken hoe WUR daar met koploperprojecten op inspeelt. ${ }^{1}$

Foto: Werken aan het Spoel (Culemborg) 


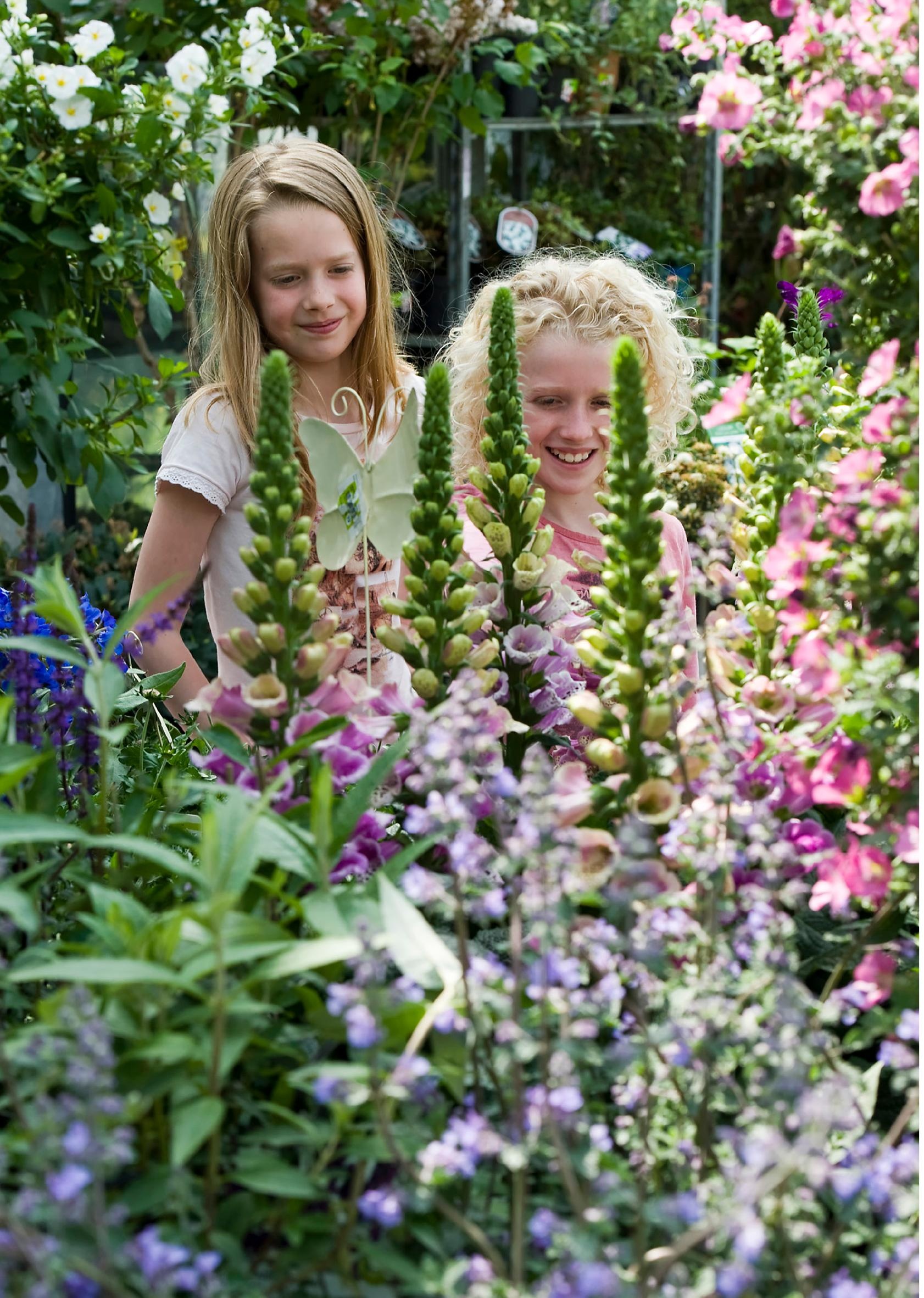
we hier aan het eeuwfeest van WUR, dat we in 2018 vieren. We doen dat door vanuit het perspectief van sociale innovatie te kijken naar de onderzoekspraktijk van nu en straks.

Anders gezegd, in het onderstaande willen we het hebben over beginselen en principes van sociale innovatie en wat hier de betekenis van kan zijn voor de onderzoeker (van WUR) en de universiteit en kennisinstelling (WUR) als organisatie. Ons betoog onderscheidt zich van verrichte studies in 'SI4VC' door het accent op onderzoek en universiteit te leggen. Maar gelijk aan veel van de uitgevoerde projecten in het sociale innovatieprogramma is het voorliggende betoog verkennend van karakter.

We proberen te ontdekken wat een sociaal innovatieve benadering kan inhouden en wat de merites kunnen zijn voor onderzoeker en onderzoeksorganisatie. Wat we naar voren brengen is een momentopname tijdens een zoekproces. We willen oproepen en uitnodigen dit zoekproces voort te zetten - ook nadat het sociale innovatieprogramma is afgerond en het jubileumjaar voorbij. We zullen in het onderstaande geen volledig uitgeruste gereedschapskist presenteren voor het toepassen van een Social Innovation Approach. En zeker niet een vol met steenbeitels die we gebruiken om in marmer gehouwen uitgangspunten, instructies en einddoelen te formuleren. We zoeken, tasten en schetsen eerder: met betrekking tot 'mogelijkheden die uit het keurslijf van achterhaalde ideeën breken'2, met betrekking tot reflectie op en relevantie van het doen van onderzoek in de wereld van vandaag en morgen. 


\section{Professoren en publiek}

Wageningen University \& Research (WUR) vierde in 2018 het 100-jarige bestaan. De onderzoekswereld van nu is in hoge mate en op vele manieren onvergelijkbaar met die van het geboortejaar van WUR. We gaan ons hieronder niet wagen aan een opsomming van de verschillen. Vooruitblikken is sowieso belangrijker voor dit betoog dan terugkijken. Maar als we een vluchtige blik op het heden werpen dan valt het oog minstens op een aspect. We zien in vergelijking met het verleden - en we hoeven hier heus geen eeuw terug in de tijd voor te gaan - dat onderzoekers momenteel volop spreken en zich het hoofd breken over het vergroten van de maatschappelijk relevantie van hun werk. Het aflopende strategisch plan van WUR heeft een ontwikkeling richting een sociaal innovatieve universiteit, die al gaande was, een verdere impuls gegeven. Dit is onder meer gedaan met het oprichten van de afdeling Corporate Value Creation en de organisatie van een aantal Wageningen Dialogues. Hiermee wordt aansluiting gezocht bij discussies die worden gevoerd over de impact van onderzoekswerk op mens en maatschappij, over hoe betekenisvol wetenschappelijke resultaten zijn voor de samenleving, of over het overbruggen van de afstand tussen professor en lekenpubliek. Onderzoek wil midden in de samenleving staan. Maatschappelijke wensen en verwachtingen als leidraad voor onderzoek nemen om zodoende de samenleving te bereiken en bedienen, impliceert tegelijkertijd dat de ivoren toren nog fier overeind staat én dat academici zoekende zijn hoe deze vaste burcht te verlaten en de buitenwereld tegemoet te treden respectievelijk 'burgers en buitenlui' toegang tot de toren te verlenen. Dit zoekproces is in belangrijke mate ook het zoekproces van het hierna volgende.

\section{Waarde van wetenschap}

Natuurlijk, ook in (vroeger) tijden van openlijke afstand tussen wetenschap en samenleving stond en staat het nodige onderzoek (uiteindelijk) in het teken van het lenigen van maatschappelijke behoeften; het aandragen van inventieve bijdragen aan maatschappelijke kwesties. Toch heeft het er alle schijn van dat 'de maatschappelijke bijdrage' vandaag de dag explicieter en doelgerichter als nastrevenswaardig kwaliteitscriterium geldt. Tenminste, onderzoeksvragen die 'van onderop' zijn opgeworpen vormden uitgangspunt voor de Nationale Wetenschapsagenda, de onderzoeksthema's van topsectoren worden mede bepaald door het bedrijfsleven, de Brusselse 'societal challenges' zijn richtinggevend voor Europees gefinancierd onderzoek en de aansluiting van onderzoek op de duurzame ontwikkelingsdoelen (SDGs) is evenzeer een hedendaagse meetlat waarlangs onderzoeksvoorstellen en -inspanningen worden gelegd. Kortom, op diverse manieren is te wijzen naar de invloed van de buitenwereld op het reilen en zeilen binnen de ivoren toren. Hoewel hier in vergelijking met honderd jaar geleden zeker een andere wind waait - mede omdat er meer buitenlucht binnenkomt - is het voorbarig te concluderen dat de academische werkplaats tegenwoordig altijd en voor iedereen de deuren en ramen wagenwijd opent. Immers, zou dat het geval zijn dan zou er veel minder noodzaak worden gevoeld de 'existentiële' vragen te stellen die we ons vandaag de dag stellen. Vragen over de maatschappelijke waarde van wetenschap - ook in het licht van academische criteria van publicatiedrift en prioriteiten van peers. Over de houdbaarheidsdatum van 'autonome' wetenschap die geen maatschappelijk contact maakt. Vragen over het nut, de noodzaak en manieren van de openstelling van het onderzoeksbastion voor invloeden van buitenaf en de consequenties daarvan voor de organisatie van kennis en de groei van kennis. Vragen over de (gezags) positie van wetenschap en onderzoek in tijden van pluriforme opinies en opiniemakers, in tijden waar nepnieuws op voet van gelijkheid staat met geverifieerde feiten en onderzoeksresultaten met een mening.

\section{Voorbode van de toekomst}

De ivoren toren mag zich, als een toren van Pisa, voorzichtig vooroverbuigen in de richting van de rest van de samenleving, hij staat nog altijd als een huis dat de deur niet automatisch open heeft staan om burgers en buitenlui toegang te verlenen, noch om academici naar buiten te laten gaan. We zien dit niet als een voorbode van de toekomst, maar stellen ons eerder voor dat een afnemende afstand tussen geleerden en leken, een buitenwacht die dringender en dwingender aan de academische poort klopt en een dito behoefte onder onderzoekers om van maatschappelijk toegevoegde waarde te zijn, aspecten zijn die in toenemende mate kenmerkend worden voor de onderzoekswereld. De openstelling voor invloeden van buitenaf verandert van kwalificatie: van uitzondering en incidenteel naar regel en regelmaat. Andersom: de impact van wetenschap op mens en maatschappij wordt een steeds belangrijkere 'maat der dingen' voor de wetenschapswereld en onderzoeker. Maar slagen we erin de afstand tussen wetenschap en samenleving te verkleinen? 


\section{Van buitenstaander tot kennispartner}

Toenemende invloed vanuit de samenleving op de academische kennisagenda betekent dat daar waar het maken van kennis, het agenderen van kennisthema's en het articuleren van kennisvragen was voorbehouden aan leden van de academische gemeenschap, niet-academici hun intrede doen om mee te praten over kennisontwikkeling, onderzoeksprogrammering en -processen. De positie die zij intussen in het Nederlandse en Europese onderzoeksland hebben verworven, kenschetst dit (democratiserings)proces. Hierna en hiernaast is steeds nadrukkelijker aan de orde dat maatschappelijke intelligentie en energie hun inbreng hebben in de kennisontwikkeling. Invloeden, interesses en inzichten van buitenaf krijgen toegang tot besluitvormingsprocessen over kennisontwikkeling, waardoor buitenstaanders, variërend in organisatiegraad en professionalisme van geïnformeerde maatschappelijke organisaties tot geïnteresseerde leken, als kennispartners, als actieve participanten, worden betrokken en benut. De WUR heeft op dit vlak een vernieuwen Europees onderzoeksproject gedaan, onder de titel CIMULACT, met als doel de relevantie van Europese onderzoeks- en innovatieprocessen te verbeteren door burgers en belanghebbenden actief te betrekken bij het opstellen van onderzoeksagenda's op basis van reële maatschappelijke visies, behoeftes en vereisten. We komen hiermee te spreken over citizen science ('burgerwetenschap') en co-creatie van kennis en ontwikkeling van creatieve vaardigheden. De groei van kennis wordt gevoed door sociale intelligentie, die benut wordt door en toegang krijgt tot het kennisdomein. Terwijl de interactie tussen onderzoeks- en maatschappelijk veld nog vaak sterk economisch getint en gestuurd is, de paragraaf 'Maatschappelijke relevantie' in onderzoeksvoorstellen nog vaak tamelijk obligaat van inhoud is, en er nog vaak minder goed wordt stilgestaan bij mogelijke nadelen van niet-academische inbreng in het onderzoek, is te verwachten dat op deze, evenals andere, onderdelen de ontwikkelingen niet stil blijven staan.

\section{Dienstbaar aan de samenleving}

Wetenschappelijk onderzoek dat in toenemende mate 'dienstbaar aan de samenleving' in het vaandel heeft staan, gaat niet alleen over kennis die mede gemaakt wordt door mens en maatschappij, maar ook over kennis maken voor de samenleving. De verbinding tussen wetenschap en samen-

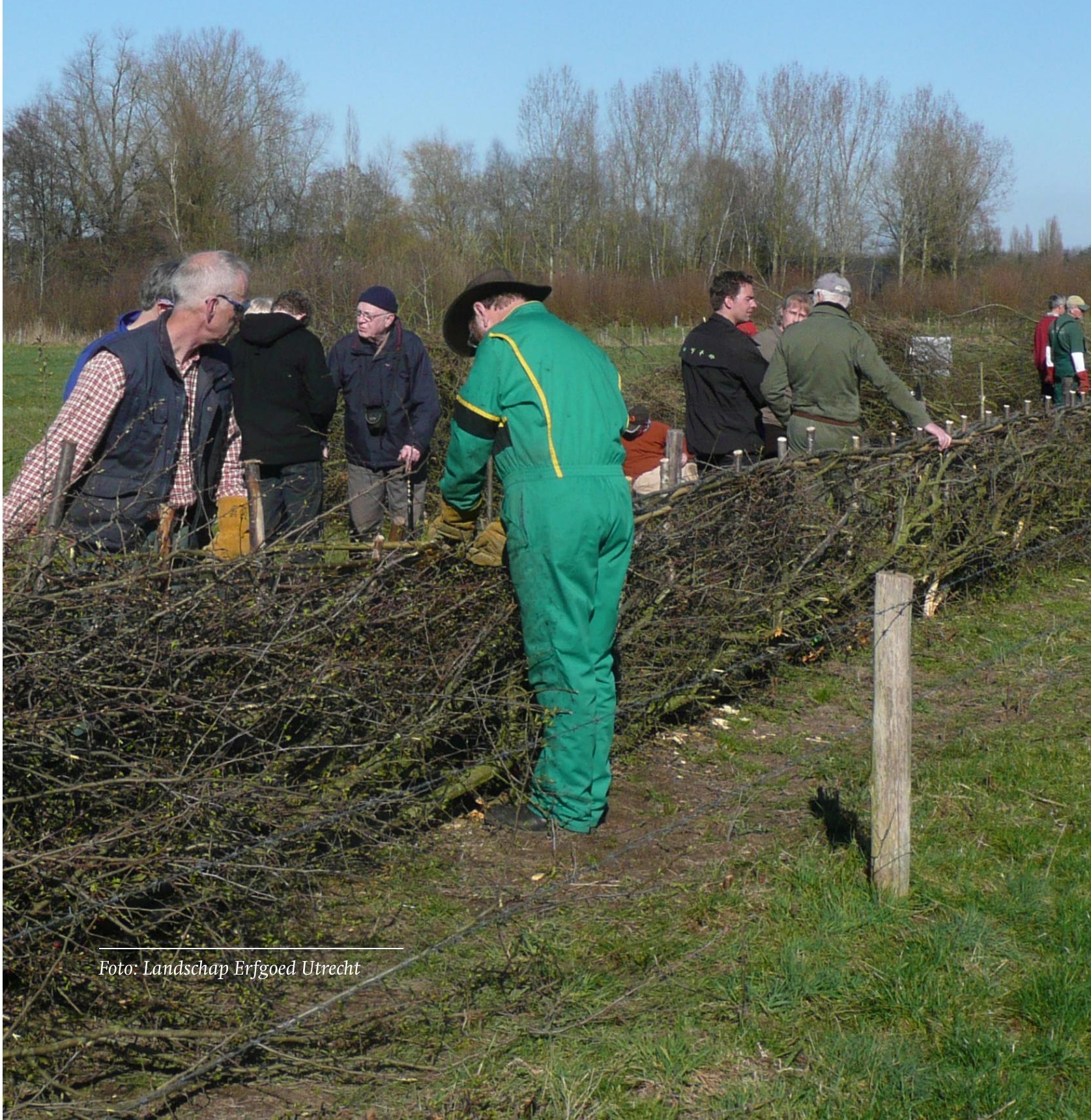


leving komt in het laatstgenoemde tot uitdrukking in het steeds serieuzer nemen van maatschappelijke uitdagingen als focuspunt van onderzoek. Wetenschap en onderzoek staan nadrukkelijk in het teken van het leveren van een bijdrage aan het bereiken dan wel dichterbij brengen van maatschappelijke doelen. Relevante kennis is kennis ten behoeve van het oplossen van maatschappelijke vraagstukken. In het navolgende zal op dit verband tussen onderzoeks- en buitenwereld de klemtoon liggen. Niet omdat de maatschappelijke invloed op het onderzoeksdomein minder belangrijk zou zijn of losstaat van de maatschappelijke betekenis van onderzoek, maar meer omdat de plaatsing van onderzoek in het licht van de bijdrage die geleverd wordt aan het geven van betere, andere, antwoorden op actuele maatschappelijke vraagstukken, ons onmiddellijk brengt bij sociale innovatie (SI).

\section{op weg naar een sociaal-innovatieve universiteit}

Ondanks dat uiteenlopende definities van SI in omloop zijn (zie kadertekst 'Wat is sociale innovatie?'), is er een breed gedeelde visie dat SI gaat over initiatieven vanuit de samenleving die collectieve doelen van die samenleving dienen. De maatschappelijke energie wordt gebundeld en gericht op het realiseren van 'publieke meerwaarde'. Sociale vraagstukken worden van nieuwe antwoorden of andere oplossingen voorzien die 'beter' zijn in termen van effectiever, duurzamer of eerlijker. Kortom, SI komt de maatschappij ten goede, zo is de veelgehoorde interpretatie. Een interpretatie die direct in overeenstemming is met het zojuist aangestipte (toekomst)beeld van wetenschappelijk onderzoek dat dienstbaar aan de samenleving is. Hoewel de inhoud, rol en betekenis van SI op diverse domeinen de voorbije jaren is verkend, is dit nog nauwelijks specifiek gedaan via het exploreren en expliciteren van de betekenis(sen) van SI voor universiteit en academisch onderzoek. Daar willen wij het hier met name over hebben. We willen aangeven dat het vinden van de weg naar een sociaal-innovatieve universiteit vraagt om een nieuw kompas en om het (durven) inslaan van ongebaande paden. Beide zijn belangrijk in de concretisering van de wijze waarop WUR SI kan incorporeren en zich ermee kan en wil profileren.

\section{Wat is sociale innovatie?}

Er is een keur aan definities van sociale innovatie (SI) in omloop en daardoor bestaat geen compromis over de betekenis van het begrip. De populariteit van SI is waarschijnlijk mede een gevolg van het feit dat het een 'rekbaar' begrip is dat op diverse manieren inhoud is te geven en van toepassing kan worden geacht. Er is, al met al, meer overeenstemming over het belang van SI dan over de exacte betekenis ervan. ${ }^{3}$ Dit neemt niet weg dat veel omschrijvingen variaties op soortgelijke thema's zijn en bepaalde definities meer navolging krijgen dan andere. Een veelgebruikte definitie van SI bijvoorbeeld is het bereiken van maatschappelijke doelen met sociale middelen. Dit is ook de definitie van de Europese Commissie. Het kan vertaald worden in het werken aan maatschappelijke doelen voor en door de samenleving zelf. Een meer fundamentele formulering hiervan betreft de verandering van instituties en institutionele machtsstructuren in de samenleving, die het gevolg zijn van informele bottom-up initiatieven met sociale doeleinden. Er is ook een andere definitie die meer op toepassing gericht is en nadruk legt op aanpassing van de methode van werken in de richting van meer interactie met de samenleving, zodat als gevolg daarvan meer sociale impact kan worden bereikt met onderzoek en vervolgens de acceptatie van technologische onderzoeksresultaten daar wel bij vaart. Kort gezegd gaat het hier om de licence to produce van technologische kennis. In beide definities zit normativiteit. De fundamentele definitie is het minst normatief, maar toch gaat deze ervan uit dat verandering en het openbreken van machtsconstellaties goed is. De tweede definitie is normatief naar de technische kant: techniek verbetert ons bestaan, maar mensen begrijpen dat niet altijd. Techniekfilosofen buigen zich over de vraag hoe technologische vooruitgang in de wetenschap zo geformuleerd kan worden dat het aansluit bij de taal van gewone mensen. Op deze manier proberen ze het kennisgat te dichten. ${ }^{4}$ Hoezeer genoemde definities in de praktijk van elkaar kunnen verschillen, voor dit betoog zijn ze beide relevant. Sociale innovatie vindt voor ons plaats in de samenleving en is daarmee een maatschappijverschijnsel (conform de eerste en meer fundamentele definitie). Maar sociale innovatie die gelokaliseerd wordt in de methode van werken in het onderzoek en de communicatie daarover (conform de tweede en toegepaste definitie), is voor ons eveneens relevant. In combinatie kijken we dan naar de rol van kennis en wetenschap in het ontstaan van nieuwe maatschappijstructuren die het gevolg zijn van sociale en informele bottom-up initiatieven. 


\section{Grondhouding van samenwerken}

Verbinden met de samenleving vereist een grondhouding van samenwerking. Ondanks dat iedereen van zichzelf het idee zal hebben dat samenwerking vaak voorkomt is het daarmee nog geen grondhouding. Het is wetenschappers eigen om te strijden voor het eigen gelijk. Daarmee is wetenschap een strijdtoneel geworden. ${ }^{6}$ Het strijden is onderdeel van de institutionele cultuur. Bij strijd zet je alles op alles op dat ene punt te maken ten opzichte van collega-wetenschappers, in tegenstelling tot samenwerking waarbij je veel breder kijkt waar je elkaar kunt aanvullen en versterken om problemen in de samenleving op te lossen. De discussie over de afname van de insectenfauna laat dit mooi zien. Iedereen kan dit met eigen ogen zien en er is sprake van een groot probleem in de wereld van bestuiving van planten. In China zijn er gebieden waar de bestuiving door mensen moet worden overgenomen, die met kwastjes het stuifmeel naar de stempel moeten brengen. Maar in de wetenschap woedt er strijd. Het onderzoek dat de afname moet laten zien rammelt en daarmee kunnen de conclusies van tafel. Er deugt helemaal niks van wordt er dan gezegd. ${ }^{7}$ De kritische onderzoekers willen het onderzoek zelf opnieuw doen. Een andere houding zou kunnen zijn dat de studie misschien tekortkomingen bevat waar je als collega op in kan springen om het geheel aan kennis te vergroten. Samenwerking als basishouding dus. Dit lijkt heel logisch, maar de werkelijkheid is vaak anders. Een grondhouding van samenwerking komt ook tot uiting in de manier waarop het eigenaarschap van kennis tot stand komt. Er zijn veel voorbeelden van onderzoek waarin burgers worden gemobiliseerd om gegevens aan te dragen en uiteindelijk geen toegang krijgen tot de kennisresultaten. Zo zijn het lezen van brieven uit de Gouden Eeuw, het invullen van enquêtes, het meten van verontreiniging met een smartphone allemaal nuttige vormen van citizen science, maar het levert vaak nauwelijks citizens' science op. De wederkerigheid zou beter kunnen en mogen.

\section{Buiten de lijntjes kleuren}

SI is niet alleen een uitdagend concept, het concept daagt ook zelf uit. Het eerstgenoemde wordt echter in bredere kringen onderschreven dan het laatste. Er is de voorbije jaren juist eerder de tendens het 'rebelse karakter' van SI te veranderen door het als het ware te neutraliseren door het concept in te bedden in het conventionele (innovatie)repertoire met bijbehorende benaderingswijzen en oplossingsrichtingen die de gevestigde orde niet fundamenteel in gevaar of opspraak brengen. Dit betekent dat het geen vanzelfsprekendheid is dat SI per definitie tegen de hoofdstroom ingaat door het gebruikelijke, vertrouwde en geaccepteerde uit te dagen en het alternatief en de polemiek te zoeken. SI in termen van verbetering van het bestaande zonder de gevestigde orde of logica zelf te veranderen, maakt SI 'keurig' inpasbaar aan de 'normale gang van zaken'. SI staat dan eerder in het teken van het bestendigen en beschermen van de status quo in plaats van met het bestaande en bekende te botsen of te breken. SI als 'inherent' rebels, als 'non-conformistische' tegenbeweging, als 'uitdager' van de status quo, wordt desalniettemin gekoesterd en waardevol geacht. ${ }^{5}$ Het idee is dat SI aan transformatief potentieel inboet als er niet buiten de lijntjes wordt gekleurd. Als we het hier hebben over een Social Innovation Approach, dan benaderen we SI eerst en vooral vanuit deze hoedanigheid. Het is in deze optiek dat SI bij uitstek de afwijkende, alternatieve positie inneemt; het uitdagende perspectief vertegenwoordigt. SI zoekt naar vernieuwende antwoorden op maatschappelijke vragen. Hiermee onlosmakelijk verbonden is wat ons betreft het gedurfde idee, het andere geluid, de onconventionele modus operandi of het bewandelen van het onontdekte pad.

\section{Verbindende kennis}

Afwijken van het bekende, een sprong in het onbekende durven maken, zijn geen kenmerken van SI omdat er per se afgeweken of gedurfd moet worden, maar omdat SI gericht is op verbetering van het bestaande. Die verbetering is te vertalen in duurzamer, rechtvaardiger, moreel juister of inclusiever. De bestaande orde schiet niet zelden tekort op deze gebieden. En hetzelfde geldt voor de wereldwijde technologische, sociale, fysieke en morele processen die samenlevingen voortdurend veranderen. De snelheid, aard en richting van die modernisering pakken zeker niet altijd en voor iedereen uit als verbetering. Pogingen om richting en 
inhoud te geven aan wat verbetering mag heten, vinden we bijvoorbeeld terug in de duurzame ontwikkelingsdoelen (SDGs). Zulke stippen op de horizon, die wijzen naar een nastrevenswaardige en moreel juiste toekomst, geven kader om te leren omgaan met veranderingen evenals een beoordelingskader welke veranderingsprocessen aangemoedigd mogen worden en welke afgekeurd of afgebouwd. Werken op basis van SDGs helpt voorkomen dat projecten worden uitgevoerd die helemaal geen draagvlak binnen de samenleving hebben of die de verschillen tussen haves en have nots blijken te vergroten. SDGs wijzen op kennis die dienstbaarheid aan de samenleving hoog in het vaandel heeft staan vanwege het cruciale belang dat gehecht wordt aan een goede - liefst: wederkerige - verbondenheid van universitair onderzoek met en inbedding in de samenleving. Een Social Innovation Approach draait om verbindende kennis.

\section{Een kompasroos van waarden}

Zoekend naar een Social Innovation Approach voor WUR - of welke andere universiteit of kennisorganisatie dan ook - willen we ons laten helpen door een waardekompas. Dit kompas, het zal niet verbazen, bestaat niet uit gefixeerde richtingen en bestemmingen die de status quo bewaken of veranderingsprocessen beheersen. Windrichtingen zijn sowieso vervangen door een kompasroos die met bepaalde waarden is ingevuld. Waarden die in het bijzonder relevantie hebben voor het maken van kennis die openstaat en bruikbaar is voor veranderingsprocessen en het leerproces hoe daarmee om te gaan. Wat staat op de kompasroos te lezen bij wijze van navigatiesysteem? We werken hieronder verschillende richtingen uit, uitgaand van het idee van verbinding zoeken om de status quo te veranderen (Figuur 1). De verbinding kan gezocht worden op het niveau van de handelende mens die verandering voorstaat vanuit individuele overwegingen of zich kan laten sturen door collectieve waarden. Verbinding kan ook gezocht worden met de samenleving, dat met het ingewikkelde landschap van instituties in hun streven tot verzorgen en ontzorgen van de mens juist reduceert tot een passief subject. Het aangaan van die verbinding kan gebeuren door actie en je daarmee letterlijk met de samenleving te verbinden of door reflectie, waarmee nagegaan kan worden onder welke condities een meer effectieve, duurzame en eerlijke samenleving kan ontstaan.

Bevrijden van de mens van normatieve kaders

die haar belemmeren tot sociaal gedrag

Reflectie

\section{Samenlevingskritiek, denken over sociale maatschappelijke verandering}

\section{Geïnstitutionaliseerde samenleving}

Methoden om samen met mensen kennis te maken voor sociale verandering

Destructie en vernieuwing van samenlevings-

structuren

We onderscheiden dus vier kompasrichtingen om verbindingen met de samenleving aan te gaan, zie figuur 2. Zoals gezegd, we zijn zoekende, 
tastende en schetsende - het gaat niet om een vaststaand beeld met duidelijke criteria waaraan voldaan moet worden. Daar zijn we nog ver van weg - en bovendien de vraag of dit haalbaar en wenselijk is. Tegelijkertijd is het wel van belang dat de onderzoeker herkenning heeft bij de geopperde richtingen. Zonder dat wordt het wel lastig een SI-benadering te ontwikkelen of hier in mee te gaan.

\section{Innovatie is mensenwerk}

De eerste richting in het kwadrant van mens en reflectie betreft de toepassing van het inzicht dat elke systeemverandering in de samenleving afhangt van de vraag of mensen bereid zijn zich anders te gedragen. Vanuit dit besef zal onderzoek dit aspect van mensenwerk mee willen nemen in de probleemstelling. Verandering houdt daarmee niet op bij de wijze waarop instituties en bedrijven met elkaar samenwerken of veranderdoelen omarmen. Ook het benaderen van burgers als anonieme consumenten ('keuzemachientjes') wiens gedrag je eenvoudig kunt sturen is niet genoeg. Veranderingen moeten in hun geheel doordacht worden, ook in hun uiteindelijke consequenties voor mensen. Onderzoek moet dan ook de mogelijkheden laten zien wanneer, waarom en hoe mensen bereid zijn actief aan veranderingen bij te dragen. Het categoriseren van mensen tot bijvoorbeeld consumenten, toeristen en migranten staat een diepere analyse in de weg waarin verkend wordt wanneer en waarom ze actief bijdragen of bij kunnen dragen aan een duurzame samenleving. ${ }^{8}$ Een voorbeeld kan gevonden worden in het massatoerisme. Niemand kiest ervoor om massatoerist te worden, niemand wil met zijn toerisme ook overlast veroorzaken aan een lokale bevolking. Massatoeristen zijn het product van een toeristenindustrie die mensen een belevenis willen meegeven in ruil voor geld. Er bestaat geen governance structuur om de aantallen toeristen te reguleren en de effecten te bestrijden, niet op nationaal en ook niet op Europees niveau. De mogelijkheid om de toerist zelf bij te laten dragen aan de oplossing van dit probleem, bijvoorbeeld door met zijn activiteiten bij te dragen aan duurzaam behoud van de kernkwaliteiten van een gebied, komt in de sector niet op. Hier is nog volop ruimte voor een SI-benadering. Het mobiliseren van alle personen die iets kunnen bijdragen aan de oplossing van een probleem is nodig om de veerkracht van de samenleving (resilience) te versterken. De Social Innovation Approach raakt hier ook aan de Europese discussie over Responsible Research and Innovation (RRI), die ingaat op de governance van wetenschap. ${ }^{9}$ Ook raakt het aan het Verdrag van Aarhus, dat het mogelijk moet maken dat milieuproblemen zo dicht mogelijk bij de mensen die er mee te maken hebben moeten kunnen worden opgelost. Het is daarbij een beginsel van subsidiariteit, die tegenwicht biedt aan het institutionaliseren en opschalen van probleem-oplossingscombinaties en deze daarmee weghalen uit het leven van gewone mensen.

\section{Methodologisch experimenteren}

De tweede kompasrichting (in het kwadrant van mens en actie) is er een van experimenteren en nieuwsgierigheid - eigenschappen die normaal gesproken niet vreemd zijn aan wetenschappers. De nieuwsgierigheid kan gaan over de vraag waar je uitkomt en wat het oplevert als je samen met burgers kennis gaat maken of als je je onttrekt aan de gangbare werkwijze en iets nieuws uitprobeert. Het kan bijvoorbeeld gaan over het ontwikkelen van nieuwe technieken. Of bijvoorbeeld over het aangaan van een samenwerking met een kunstenaar en wetende dat je hoogstwaarschijnlijk ergens uitkomt waar je vooraf geen enkel idee bij had. Het kan ook nieuwsgierigheid zijn naar wat voor sentimenten spelen in de samenleving en waarom deze zich soms en soms niet keren tegen technologische vooruitgang. Nieuwsgierigheid kan ook gericht zijn op het zoeken naar antwoorden van mensen die niks weten van een vakgebied maar wel bereid zijn in actie te komen voor een specifiek doel. Zo is er een ondernemer die het CO2-probleem wilde oplossen door het verspreiden van een gesteente, genaamd Olivijn, dat $\mathrm{CO} 2$ opneemt. Hij heeft het bedrijf Greensand opgericht dat Olivijn wil verspreiden over de wereld. Aanvankelijk werd dit niet serieus genomen door de klimaatexperts omdat het niet strookte met de heersende probleem-oplossingscombinatie, die is gericht op fossiele brandstoffen. Medewerkers van de Universiteit van Sheffield werden toch nieuwsgierig en inmiddels is het wel degelijk een lijn van serieus onderzoek geworden en komen we steeds meer te weten over het vastleggen van $\mathrm{CO} 2$ door het verweren van gesteenten. ${ }^{10}$ Een belangrijke wijze om deze waarde te hanteren is het co-creëren van kennis door gebruik te maken van of toe te leveren aan citizens' science. 


\section{Complexiteit door inclusiviteit}

De derde roos in het kompas (in het kwadrant van reflectie en samenleving) betreft onder meer het aanvaarden en hanteren van complexiteit. In de samenleving bestaan vele waardestelsels en vandaaruit ontstaan veel perspectieven op de werkelijkheid, die makkelijk als dom en niet relevant terzijde zijn te schuiven. Door de horizon van relevantie (zie kadertekst 'Horizon van relevantie') te verleggen zodat deze toch relevant worden, ontstaat complexiteit. Die complexiteit kan heel functioneel zijn, omdat ze laat zien dat deeloplossingen in het ene domein de problemen in een ander veld kunnen verergeren. Dit kom je op het spoor door de reacties van mensen op problemen en probleemoplossingen serieus te nemen - ook als ze enkel emotioneel overkomen. Wie complexiteit aanvaardt en weet te hanteren, kan goed werk doen voor het nexusdenken, dat werkelijk integraal is en zich toelegt op het nadenkenken over hoe wicked problems met elkaar samenhangen. ${ }^{11}$ Reductionisme, dat zo eigen is aan veel wetenschappelijk onderzoek, staat op gespannen voet met integraal denken dat de samenleving echt vooruit helpt. Bij het hanteren van complexiteit is samenlevingskritiek van belang. Het gaat daarbij om de vraag wat mensen afwachtend maakt en wat leidt tot slimheid en activering. Hoe kan je burgerslimheid inzetten voor het oplossen van grote problemen of voor het werken aan SDGs? Dit voegt duidelijk een element toe aan complexiteit. De gebruikelijke denkwijze van 'er is een probleem en dus hebben we een nieuw instituut nodig die dit voor ons gaat oplossen' wordt veranderd in 'er is een probleem en hoe kan dit met elkaar, kleine en grote instituties en bedrijven, plus mensen die het aangaat, opgelost worden'. Een interessant voorbeeld betreft het afvoeren van regenwater zonder dat er overstromingen ontstaan. In eerste instantie werd dit gezien als een taak van de waterschappen, maar in tweede instantie blijkt dat bewoners van een huis met een tuin in belangrijke mate kunnen bijdragen aan de oplossing. Dat vraagt om ontstening van tuinen, omdat water in een versteende tuin niet in de bodem opgevangen kan worden. Deze ontstening vindt plaats in een groot project onder de titel Operatie Steenbreek, dat qua management en organisatie nogal complex is. Wetenschappers laten zien dat groene tuinen veel koeler zijn in de zomer en dat een groene tuin goed is voor de biodiversiteit. Hier is sprake van een combinatie van waarden, een dialoog met bijna een ontelbaar aantal huiseigenaren en een goed onderkende relevantie van de stoeptegel.

\section{Destructie en vernieuwing}

De vierde richting (in het kwadrant van actie en samenleving) is er een van verzet tegen het bestaande en het willen bijdragen aan maatschappelijke vernieuwing richting een meer sociale en inclusieve samenleving. Als vertrekpunt geldt het besef dat instituties, en dus ook kennisinstellingen, zichzelf in de weg zitten als het gaat om vernieuwing. Het omvormen van maatschappelijke problemen tot een business case heeft ertoe geleid dat het in stand houden van een probleemveld profijtelijker is dan het oplossen. Geld was oorspronkelijk het middel om problemen op te lossen, maar het omgekeerde is ontstaan: problemen zijn tot middel verworden om geld te krijgen. Schuldsanering als verdienmodel bijvoorbeeld. Om dit te doorbreken is een actieperspectief nodig waarin het juiste en waarachtige belangrijker zijn dan de onderbouwing dan wel het vinden van wat gezien wordt als de waarheid. Deze kompasroos is bij uitstek bruikbaar voor wat wetenschappers 'wicked problems' noemen. Problemen waar enorm veel geld aan besteed wordt en waar een heel leger aan instituties zich over buigt, maar waar door de jaren heen weinig verbetering in te merken valt.

Het Instituut voor Publieke Waarden (IPW) richt zich op zulke problemen en hanteert daarbij een soort 'system hacking'-benadering. Ze laten zien dat kleine problemen de oplossing van grote problemen, die de maatschappij veel geld kosten, in de weg zitten. Het systeem laat het niet toe, maar met de logica van datzelfde systeem laten ze zien hoeveel geld is te besparen met het maken van een uitzondering. ${ }^{12}$ In landbouw-natuur- en economie-klimaatvraagstukken zitten tal van deadlocks die met sociale system hacking gekraakt zouden kunnen worden. Maar daarvoor moet je ze wel zien. En om ze te zien moet je begrijpen hoe een configuratie van diverse instituties er belang bij heeft om een probleem niet op te lossen. Pas als je snapt hoe dit systeem werkt, ontstaat het inzicht hoe je het van binnenuit kan veranderen..$^{13} \mathrm{Om}$ het systeem te leren kennen is het belangrijk er vanuit de marges naar te kijken. Dan valt het te overwegen om te partneren met marginale tegenstanders van het systeem, zoals de organisaties verenigd in RiseUp. ${ }^{14}$ De geëngageerde onderzoeker die deze waarde in praktijk brengt, kan heel snel een actieonderzoeker worden, die zijn/haar kennis verdiept vanuit de beweging die gaande is. De kennis die hij/zij aandraagt zal bijdragen aan het vinden van een strategie en een handelingsperspectief (actionable knowledge). De acties kunnen ingaan tegen de gevestigde orde als de onderzoeker bijvoorbeeld 


\section{Horizon van relevantie}

Een Social Innovation Approach staat of valt bij het serieus nemen van kritiek en het ingaan op vragen die van buiten de wetenschap op de onderzoeker afkomen. Hierbij speelt de horizon van relevantie een belangrijke rol, want deze bepaalt of deze worden weggewuifd of dat er serieus naar gekeken gaat worden. Ligt de horizon dichtbij, dan is een vraag al snel niet relevant. Ligt de horizon ver weg, dan is zelfs emotionele kritiek ook een vorm van kennis waar een onderzoeker op in kan gaan of gebruik van kan maken. Hij/zij bepaalt dus in belangrijke mate de inclusiviteit van onderzoek. We leggen hieronder uit waar die horizon van relevantie nu eigenlijk door bepaald wordt. In de regel zijn er drie soorten vragen binnen de domeinen van het bekende, het gekende onbekende en het ongekende onbekende. Vragen van de eerste soort zijn beantwoordbaar door de vragensteller zelf. Vragen van de tweede soort zijn beantwoordbaar, maar het vereist onderzoek of een andere persoon om die antwoorden te vinden. Vragen van de derde soort zijn notoir lastig, want het is niet duidelijk of het zinvolle vragen zijn waarop een antwoord mogelijk is. De grens tussen de tweede en derde categorie wordt bepaald door de zogenoemde horizon van relevantie. ${ }^{15}$ Iedereen heeft zo'n horizon, maar waar deze ligt verschilt van mens tot mens. Die horizon van relevantie wordt sterk bepaald door de institutionele context waarin gewerkt wordt. Een voorbeeld. Iemand die zich identificeert met een sterke overheid zal het niet zo relevant vinden om te weten wat vrijwilligers allemaal doen voor elkaar naast het vrijwilligerswerk. Onderzoek daarnaar valt voor deze persoon in de categorie 'nice to know'. Diens horizon houdt op bij de bijdrage die vrijwilligers leveren aan het bereiken van overheidsdoelen. Iemand die naar vrijwilligerswerk kijkt vanuit het perspectief van de participatiesamenleving zal dit juist heel interessant vinden. Zijn/haar horizon ligt verder weg, omdat hij/zij het institutionele landschap niet als een vast gegeven ziet, maar als iets dat uitgedaagd en veranderd moet worden. Iemand die zo'n perspectief hanteert, zal geïnteresseerd zijn in wat personen in een concrete context doen. Een horizon van relevantie is natuurlijk een sociaal construct. Het zijn groepen onderzoekers die aan een onderwerp werken die met elkaar bepalen wat wel en niet relevant is en in welke richting de vooruitgang in kennis gezocht moet worden. Hier schuilt uit de aard der zaak het gevaar van 'zelfreferentialiteit', te weten het onwillekeurig begrenzen van hetgeen als zinvol en relevant beschouwd moet worden als product van groepsdenken. Door te morren aan institutionele kaders, ze liefst weg te denken, en door concepten als burgers, patiënten, consumenten bewust niet te hanteren maar vooral te kijken naar diversiteit aan personen en welke persoonlijke kennis en motieven daarbinnen besloten liggen, wordt de horizon van relevantie verruimd die mogelijkheden schept voor een Social Innovation Approach. Het verruimen van de horizon leidt er immers toe dat meer schijnbaar irrelevante vragen toch beantwoordbaar en zinvol blijken te zijn. Dit zullen vaak vragen zijn die buiten de gevestigde kaders vallen. laat zien wat de meerwaarde is van een 'commons-benadering' in het gebruik van natuurlijke grondstoffen, of als inclusieve businessmodellen worden aangereikt. Kritiek op bestaande praktijken en het aandragen van alternatieven gaan hand in hand. Een mooi voorbeeld betreft een wetenschapswinkelproject waarin is nagegaan of de Afrikaanse Diaspora een rol van betekenis kan krijgen in het proces waarlangs het buitenlandbeleid van de Nederlandse overheid vorm krijgt. Dit heeft geleid tot een motie in de Tweede Kamer en een beweging genaamd Africa in Motion. Het voorbeeld laat zien dat kennis een doorslaggevende rol kan spelen in vernieuwing van onderop.

\section{Handelen volgens het waardekompas}

$\mathrm{Nu}$ de richtingen in het waardekompas van de SI-benadering zijn geschetst, is het vervolgens de vraag hoe daarnaar te handelen. In de tussenstap van waarden naar handelen spelen sociale principes een belangrijke rol. Principes gaan over de verbinding tussen kernwaarden, ideologische uitgangspunten en operationele keuzes in het werk. Het zijn keuzes waar iemand niet zo makkelijk van is af te brengen, omdat ze uitdrukking geven aan iemands kernwaarden. Vandaar dat principes zich niet of lastig laten delen als de kernwaarden niet herkend worden. Als we hieronder de vier kompasrichtingen vertalen in een aantal principes van sociale innovatie, hoeft het niet zo te zijn dat de Social Innovation Approach vereist dat alle principes worden gehanteerd, maar toch tenminste wel enkele. Evenmin betogen we hier dat de benoemde principes een dekkend overzicht geven - noch dat dit zelfs maar kan.

\section{Waardegericht werken}

Misschien de belangrijkste overkoepelende opgave is die van waardegerichtheid ten aanzien van een maatschappelijk vraagstuk. Met waardegericht werken ontstaat maatschappelijk kapitaal dat niet zo snel te vertalen is in geld, zoals cultureel, sociaal en ecologisch kapitaal. Het werken aan nature-based solutions waarin we leren om natuurlijke processen in te zetten voor het oplossen van maatschappelijke problemen, kan bijvoorbeeld leiden tot ecologisch (de natuurvriendelijke oplossing) en cultureel kapitaal (toevoeging van een nieuwe oplossingsmethode aan het bestaand repertoire). Hier lopen we dan aan tegen het feit dat waar- 
degericht werken niet hetzelfde is als klantgericht werken in de zin van ' $u$ vraagt, wij draaien'. Waar bestaat die waardegerichtheid dan uit? Voor een specifieke klant is onderzoek waardevol als het bijdraagt aan meer winst, al dan niet via het verbeteren van efficiëntie of concurrentie. Vaak wordt dan gesproken over valoriseren van kennis. Om maatschappelijke waarde te creëren is het vaak interessanter om het idee van efficiëntie en winst los te laten en te kijken hoe een probleem met sociale middelen en vanuit sociale doelen opgelost kan worden. Daarvoor is een combinatie nodig van empowerment van allen die een steentje kunnen bijdragen en het daartoe aanreiken van een actie-en handelingsperspectief. Kennis moet dan aansluiten op de kennis die actoren zelf hebben verkregen of gemaakt over het onderwerp waar energie op zit (Citizens' science).

\section{Spanningsvolle principes}

Het hanteren van de aangedragen principes roept uit de aard der zaak spanning op met de gangbare manier van werken. Dat moet ook schuren, want anders zou er geen sprake van innovatie zijn. Zo schuurt bijvoorbeeld het principe van insluiting of inclusiviteit met het idee van klantgericht werken. Inclusiviteit geldt dan voor het netwerk waarin je samenwerkt (een open netwerk dus), het betrekken van onbekende spelers in een maatschappelijke opgave en het laten toevallen van waarden aan een grote groep, bijvoorbeeld door middel van een commons georienteerd business model. ${ }^{16}$ Dit wijkt af van een klantgerichte benadering, want daarin wordt gestreefd naar waardemaximalisatie voor enkel de

klant die het onderzoek betaalt. Dit kennen we als vraaggericht werken. Opgavegericht werken is anders, want hierin probeert de onderzoeker een vraagstuk verder te brengen en veel meer stakeholders tot actie aan te zetten. Een ander vlak waarop het kan schuren betreft het werken volgens een vooraf expliciet gemaakte ideologie enerzijds en het onafhankelijk zijn als wetenschapper anderzijds. Principes en ideologieën liggen dichtbij elkaar. Mensen zijn zich vaak wel bewust van hun principes, maar veel minder van de ideologie waarbinnen ze hun activiteiten ontplooien. Met een principiële keuze kan je aangeven vanuit welke ideologische uitgangspunten je je werk doet. De ideologie van 'backing winners' (het ondersteunen van de besten die uiteindelijk zullen zorgen voor een trickle down effect van inkomsten voor de achterblijvers) is bijvoorbeeld heel verschillend van een commons-benadering (waardecreatie voor iedereen). Het zal weinig of niet voorkomen dat onderzoekers kleur

\section{Innovatie is} mensenwerk

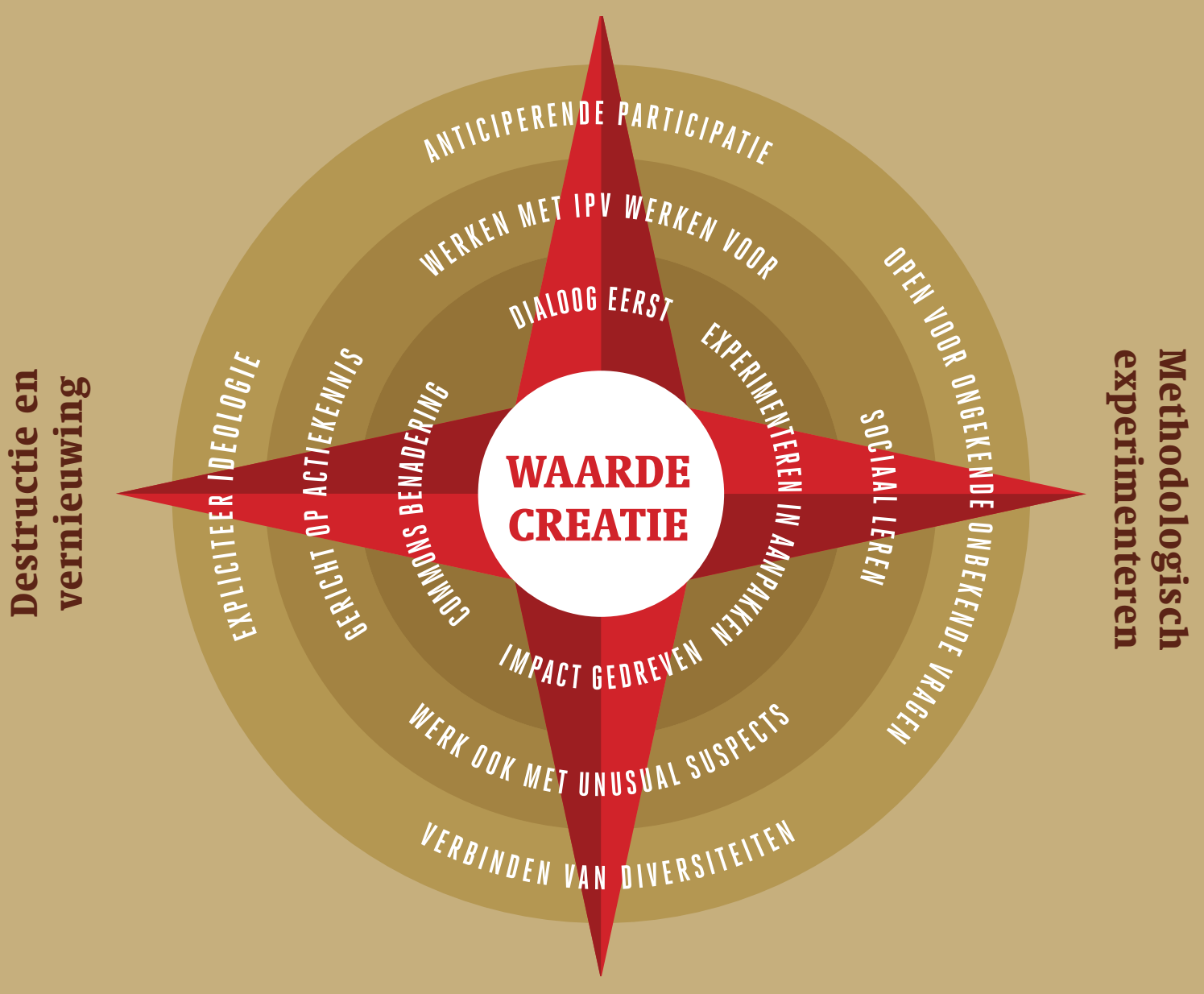

Complexiteit door inclusiviteit

FIGUUR 2

Ben kompas voor waardecreatie 
bekennen over de ideologie van waaruit ze hun werk doen. Maar onderzoek volgens de ene of de andere ideologie zal grote verschillen kunnen laten zien. Voorbeelden van backing winners zijn aanwezig in het topsectorenbeleid, terwijl bijvoorbeeld in het smart city-onderzoek veelvuldig de commons approach terug is te vinden. Het gaat in dit laatste geval om onderzoek dat gebruikmaakt van de intelligentie van het publiek. Het is de vraag of je je als onderzoeker altijd bewust kunt zijn van de ideologische kaders waarbinnen je opereert of daar door derden op gewezen moet worden. Door hier een principieel standpunt in te nemen kan dat bewustzijn groter worden. Het zal dan minder moeite kosten om te beseffen dat sommige ideologieën, zoals diegenen die enkel uitgaan van marktwerking of van een regievoerende en regulerende overheid, zich ongemakkelijk verhouden tot een SI-benadering. ${ }^{17}$

\section{Competenties van sociaal innovatief werken (1)}

De Social Innovation Approach vraagt om specifieke competenties. Een voor de hand liggende competentie is het kunnen vormgeven van een constructieve dialoog met niet-wetenschappers waarin de grenzen van ons conceptuele denken worden onderzocht, zoals die tussen techniek en sociaal, of tussen economisch en sociaal. Daar komt een andere competentie bij kijken, namelijk het vermogen tot reflectie en zelfreflectie met betrekking tot een thema en het belang van het eigen onderzoek daarin. Er is namelijk een zekere mate van relativering nodig die helpt om je open te stellen voor andere perspectieven op een vraagstuk of het vinden van slimme aangrijpingspunten van verandering (denk aan het voorbeeld van system hacking). Hiervoor moet je weten welke mindset en waarden de status quo laten voortduren, en of er openingen zijn voor nieuwe spelregels die een invloed van onderop mogelijk maken. Belangrijke waarden in het openbaar bestuur zijn efficiëntie en gelijke behandeling. Dat kan 'gehackt' worden met een ander argument, bijvoorbeeld dat iets goedkoper kan als mensen in staat worden gesteld met hun eigen oplossing te komen. ${ }^{18}$ Een volgende competentie en bovendien een van de belangrijkste is het vermogen om vast te stellen wat waardevol is en waar behoefte aan bestaat in termen van kennis voor verandering. De behoefte aan verandering komt veelal voort uit zorgen, zoals zorgen voor veiligheid en geborgenheid, voor gezondheid of voor het milieu. Een sociaal innovatieve wetenschapper weet via dialoog juist daar de innovatieopgave uit te destilleren. Als bijvoorbeeld een groeiende groep jonge- ren een app gebruikt om zwangerschap te voorkomen, dan kan je daar op reageren dat dat hoogst onverstandig is en dat ze daar de betrouwbare middelen voor moeten gebruiken. ${ }^{19}$ Maar als hij/zij goed luistert, dan verneemt hij/zij de zorgen over bijvoorbeeld het dagelijks innemen van hormonen en stelt de onderzoeker zich de vraag of er een alternatief ontwikkeld kan worden dat deze zorgen wegneemt. Een innovatieopgave wordt zichtbaar door boven de wie heeft gelijk-discussie uit te stijgen.

\section{Competenties van sociaal innovatief werken (2)}

Integraal werken behoort eveneens tot de competentie. Nu is integraal momenteel een populair begrip, en we bedoelen hier dan ook méér dan het integreren van andere vakgebieden. Integraal heeft hier de betekenis dat je je kunt verbinden aan de samenleving die in verandering is met waardevol onderzoek. Dit doe je door diep te doordenken hoe veranderingen zich voltrekken of in beweging worden gezet als resultaat van mensenwerk. Het ontwikkelen van kennis met een actieperspectief noemen we transdisciplinair werken. De Social Innovation Approach vraagt nog een verdere stap van integraliteit via het verbinden van emotie als kennis aan ratio. Emotie kan gezien worden als een snelle vorm van ervaringskennis en zou niet buiten de horizon van relevantie moeten liggen. De filosofe Martha Nussbaum heeft uiteengezet dat emoties gezien moeten worden als waarderingen van objecten en personen die deels buiten de controle van het individu vallen, en zeer belangrijk zijn voor diens welbevinden. Als we emoties zien als waardering en snelle ervaringskennis, dan wordt duidelijk dat die niet te veronachtzamen zijn in de productie van kennis. ${ }^{20}$ De veel gehoorde uitspraak dat burgers vooral hun emoties uiten en wetenschappers feiten produceren is dan ook de dood in de pot voor een Social Innovation Approach. Een goed concept voor deze vorm van integraal werken bestaat nog niet, maar we zouden het wellicht 'post-disciplinair' kunnen noemen.

\section{Competenties van sociaal innovatief werken (3)}

Het vernieuwen van methodes van onderzoek als creatief zoekproces richting de co-creatie van kennis, is eveneens een belangrijke competentie. Een natuurlijke en effectieve manier om je als onderzoeker te verbinden aan maatschappelijke opgaven en veranderingen is het doen 
van participatief actieonderzoek. De kennis wordt hier samen met actieve burgers en bedrijven ontwikkeld. Om dit te kunnen is het als onderzoeker belangrijk te kunnen loslaten en delen. Loslaten omdat je de controle over materiaal en methoden deels verliest, waarmee je kwetsbaar kunt worden voor collega's. Het delen houdt in dat de kennis primair tot doel heeft om problemen op te lossen door middel van het activeren van mensen die werken vanuit een goed geïnformeerd handelingsperspectief. Kennis en actie ondervinden een wisselwerking. Dit klinkt eenvoudig, maar is het niet. Als wetenschapper ben je vrijwel altijd onderdeel van een machtsconfiguratie die gespitst is en/of toegerust is op het bestendigen van de status quo. Toch vindt juist hier ook het experiment plaats, zoals in de hoek van Utopisch Onderzoeksdesign. ${ }^{21}$ Dan wordt volop nagedacht over de relaties van onderzoek met dominante ongelijkheden in de samenleving. De co-productie van kennis wordt gezien als het bieden van ruimte om aan utopische denkbeelden en strategieën te werken. ${ }^{22}$

\section{Heikele onderwerpen (1)}

In het bovenstaande hebben we het gehad over kompaswaarden en de richtingen die ze aangeven, over principes en competenties om tekst en uitleg te geven aan een Social Innovation Approach. We beseffen, het gaat om tamelijk algemene termen waarin we invulling aan deze benadering hebben gegeven. Veel verder kunnen we niet gaan zonder daarbij in de bijzonderheden terecht te komen van specifieke thema's of vakgebieden. In soortgelijke algemene termen willen we dit betoog richting een afronding brengen. Alvorens het voorafgaande tot een schema te comprimeren in de slotparagraaf, richten we de aandacht daaraan voorafgaand op enkele 'heikele' punten, oftewel luis-in-de-pels-onderwerpen, die hier kort benoemd, én later en door anderen verder overdacht, mogen worden als we het willen hebben over hoe verder met een Social Innovation Approach. We concentreren ons hierbij op vier punten die we op de agenda willen plaatsen als het gaat om de implementatie van een Social Innovation Approach (in WUR). Een Social Innovation Approach vraagt om (i) een andere logica, (ii) een andersoortig bestuur, (iii) een ander soort kennis en (iv) nieuwe organisatievormen die breken met de oude. Geen geringe onderwerpen, we realiseren ons dit terdege. Onderwerpen waar de academische wereld, wat ons betreft, verder op blijft reflecteren. Onderwerpen ook die wij hieronder slechts even de revue kunnen laten passeren. Met betrekking tot logica (@i) is te denken aan versterking van een andere

\section{Naar een praktijk van leren en experimenteren: WUR en INRA}

In de praktijk van WUR zijn veel kiemen te vinden van een Social Innovation Approach. Om die verder tot groei en bloei te laten komen is experimenteerruimte nodig evenals het ruimte bieden aan vragen die de horizon van relevantie van WUR verlegt evenals uitnodigt nieuwe methoden van (actie)onderzoek te ontwikkelen. Mooie voorbeelden hiervan zijn te vinden in de vragen die via de Wetenschapswinkel aan WUR worden gesteld. Ruimte voor experiment, en leren van dat experimenteren, zijn van vitaal belang voor de verdere ontwikkeling van een Social Innovation Approach. Bij een bevriend instituut in Frankrijk, het INRA, worden positieve ervaringen opgedaan. We lichten dit 'lichtend voorbeeld' voor WUR kort toe in deze kadertekst.

In Frankrijk is de strijd op zulke gebieden als nanotechnologie, gentech of pesticiden altijd een heel stuk feller dan in Nederland. Wie herinnert zich niet Bouvé, de antiglobalist, op de barricaden tegen het beleid van Chirac. Nauwelijks verwonderlijk dat in Frankrijk al enkele decennia terug een discussie op gang kwam over transparantie in de wetenschap en het doen van participatief onderzoek. Wetenschappers werden daar uitdrukkelijk toe uitgenodigd door de overheid. De discussie kwam op gang onder invloed van de BSE ('Gekkekoeienziekte'). Het INRA, een zusterinstituut van Wageningen Research, begon met het experimenteren van participatie in het onderzoek door mensen die niet op de hoogte zijn van de methoden van wetenschappelijk onderzoek. Dit deden ze bijvoorbeeld in gevoelig onderzoek naar een mogelijk bewustzijn van dieren. Het INRA definieert Science and Partici- patory Research als een manier om wetenschappelijke kennis te vergaren in een samenwerking tussen onderzoekers, maatschappelijke actoren - zowel individueel als collectief - op een actieve en doelgerichte manier. INRA maakt hierbinnen onderscheid tussen citizen science, participatory action research en community based research. Deze ontwikkeling werd intern aangejaagd door een kritische groep onder de naam 'Sciences en question' ${ }^{23}$, die tal van zaken zoals new public management en property rights vanuit ethisch perspectief bediscussieerden en daar ook over publiceerden. Er ontstond langs deze weg een institutionele cultuur van de samenleving betrekken bij het onderzoek, die wordt gedragen door nu al meer dan 100 onderzoekers die zo werken. De werkwijze is vastgelegd in een Charter, mede ondertekend door de overheid. Het gevolg van deze institutionele cultuurverandering is dat mensen meer vertrouwen hebben in de uitkomsten van onderzoek, dat er veel nieuwe interdisciplinaire vragen opkomen en dat het werkplezier van de onderzoekers is toegenomen. ${ }^{24}$ Het INRA-voorbeeld biedt inspiratie aan de verdere groei en bloei van een SI-benadering binnen het onderzoek van WUR. Te trekken lessen zijn dat het helpt wanneer er draagvlak voor is vanuit het ministerie van LNV, het management en ook ingebed is in de organisatiecultuur. Dit alles is niet iets dat lukt van de ene dag op de andere, maar is een proces van lange adem. 
logica dan de conditionerende werking van geloof en ideologieën die zijn verworden tot een geïnstitutionaliseerde logica, zoals het neoliberalisme, het adagium Van Aid naar Trade, of het heilige geloof dat de techniek het menselijk bestaan zal verbeteren. Juist in de opvatting dat wetenschap waardevrij is en objectief schuilt het gevaar dat het ongemerkt meegaan in een bepaalde ideologie afbreuk doet aan diezelfde veronderstelde onafhankelijkheid. Het is te overwegen veel bewuster en explicieter te zijn in de productie van kennis omtrent binnen welke ideologische setting deze plaatsvindt en hoe deze setting zich voordoet in de vorm van een configuratie van macht die (onbedoeld) de status quo wil handhaven. Hoe meer men het tegenovergestelde doet, te weten het beroepen op de onafhankelijke en onaantastbare status van wetenschap, hoe sterker de ontkenning of negatie van een ideologische setting. Het alternatief is dat expliciet wordt gemaakt welke waarden worden nagestreefd in een onderzoek, en aan wie die waarden kunnen toevallen. Dit is een andere vorm van transparantie dan de gebruikelijke methodologische verantwoording.

\section{Heikele onderwerpen (2)}

Met betrekking tot sturen en besturen van kennisontwikkeling (@ii) zouden de overpeinzingen gericht mogen zijn op het dieper wegleggen van de strategie-ontwikkeling in de organisatie (decentrale strategievorming). Dan zou een vorm van sturing tot stand kunnen komen die meer gericht is op het relationele dan op het financiële. Ook hier geldt weer dat het de individuele werknemers en de kleine teams zijn die zich verbinden aan kleine vernieuwingsinitiatieven in de samenleving, terwijl de hogere echelons werken aan strategische institutionele arrangementen. Beide zijn belangrijk, maar in het denken over resultaat en impact zou meer aandacht mogen komen voor situationeel management en zelfsturende teams die zijn gedreven door sociale ondernemendheid. ${ }^{25}$ Reflectie op welke kennis nodig is (@iii) in een veranderende wereld is een doorlopende kwestie. De participatiesamenleving vraagt om andere kennis dan de verzorgingsstaat van de 20e eeuw. Het automatisme om kennis te richten op overheden of op instituties die een probleem voor de samenleving oplossen, is in feite permanent te bediscussiëren. Dit kan bijvoorbeeld de vorm krijgen van een reflectiegroep die zich buigt over issues van wantrouwen die in de media terechtkomen en de positie van de universiteit ondermijnen. Zulke issues kan je slechts zien als een gevaar, en dan moet je ze direct de kop indrukken. Maar ze kunnen ook bekeken worden vanuit het idee dat ze wellicht een terecht punt hebben, dat mensen de wetenschap opzoeken om er een inhoudelijk conflict mee aan te gaan, hetgeen kan leiden tot een wens om de organisatie te veranderen. Een dergelijke benadering zal bijdragen aan het ontwikkelen van de genoemde 'post-disciplinaire' werkwijze als onderdeel van een Social Innovation Approach.

\section{Heikele onderwerpen (3)}

Met betrekking tot organisatievormen (@iv) waarin gewerkt wordt, is om te beginnen nader in overweging te nemen hoe verstarrend bepaalde vormen van kennisorganisatie (uit)werken. Vervolgens is in ogenschouw te nemen hoe sterk, (on)gewild en (on)gemakkelijk onderzoeken en onderzoekers bijdragen aan het handhaven van de gevestigde orde, een bepaalde mindset of belangen voor lief nemen die maken dat organisatievormen prikkels verliezen om (radicaal) te vernieuwen. ${ }^{26}$ Hier speelt ook de kwestie hoe een organisatievorm bijdraagt aan naar buitengericht zijn (een 'extraverte' universiteit of kennisinstelling) en op het ontwikkelen en onderhouden van verbindingen met de buitenwereld. Het transparant en permeabel maken van de grens tussen kennisorganisatie en samenleving kan op vele manieren en in vele vormen worden opgepakt. Bijvoorbeeld in de vorm van samenwerking met juist niet-academische mensen. Of door een verbindende schakel (nexus) te zijn in de trade off-relaties tussen verschillende probleemvelden en stakeholderconfiguraties, zoals de Economic and Social Research Council nastreeft in Engeland. ${ }^{27}$ Maar ook door het actief bevorderen van participatief actie-onderzoek, living labs en vele andere werkvormen waarmee de onderzoeker diens werkveld verlegt naar de buitenwereld en erkent dat leken een belangrijke bijdrage kunnen leveren aan de kennis die nodig is om problemen op te lossen. Het valt in dit kader eveneens te overwegen om in de strategische ontwikkeling van werkvelden momenten in te lassen waarop wordt nagegaan hoe de interactie met de samenleving intensiever en vruchtbaarder vorm is te geven. ${ }^{28}$ 


\section{Kijkend over de drempel}

\section{Individueel}

KOMPAS

VAN SI

\section{Collectief}

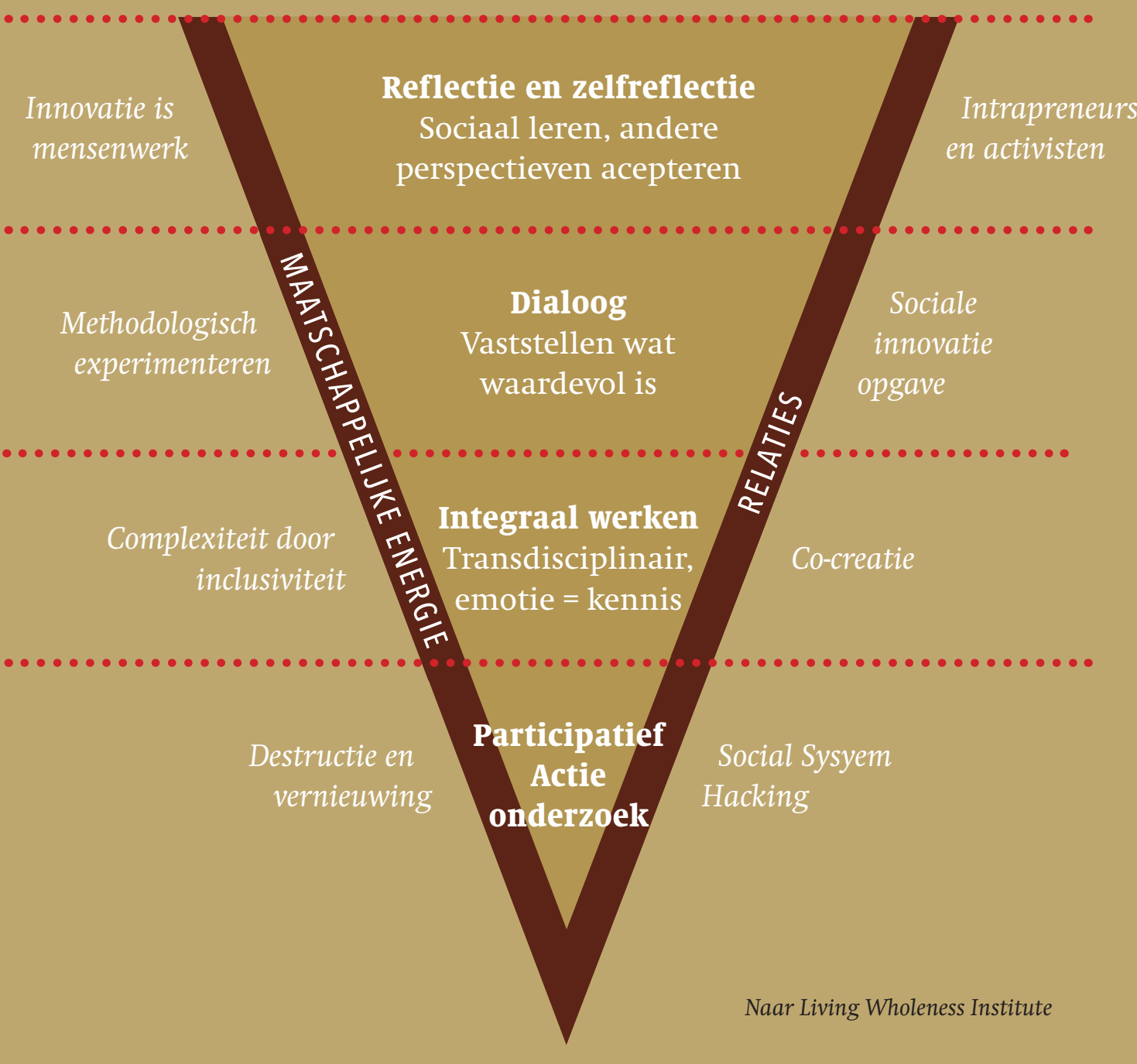

FIGUUR 3
UITKOMSTEN

VAN PRINCIPES
Competenties

Als we nu de belangrijkste elementen van een Social Innovation Approach samenbrengen in een overzicht, dan ontstaat nevenstaand figuur. Zonder dat alles een plek heeft gekregen in deze figuur, is de bedoeling ervan in een oogopslag een beeld te krijgen van het handelingsperspectief dat een kennisinstelling heeft om bij te dragen aan het in de praktijk verder laten uitkristalliseren van een Social Innovation Approach, die we hier geprobeerd hebben onder woorden te brengen. Het was ons hierbij niet te doen om tot een receptenboek of tool box te komen, maar om een uitnodiging te doen hierin te participeren. Een uitnodiging om mee te doen ook omdat we nu op de drempel staan naar een volgende eeuw voor WUR. Kijkend over die drempel zien wij het belang van een Social Innovation Approach eigenlijk alleen maar groeien. Wij voorzien de maatschappelijke inbedding en dienstbaarheid van universiteit en onderzoeksinstituut, waar we het eerder in dit betoog over hadden, groter en belangrijker worden. Een toekomstbestendige universiteit of kennisinstelling is maatschappelijk ingebed en dienstbaar. Het zou ons niet verbazen wanneer publicatie- en specialisatiedrang onder toenemende maatschappelijke druk komen te staan en 'buitenstaanders' zich indringender met het reilen en zeilen binnen de ivoren toren gaan bemoeien. Andersom, dat de tendens die zich de voorbije tijd laat onderkennen waarin de onderzoekswereld zoekt naar maatschappelijk contact en mikt op maatschappelijke impact, zich doorzet, verder intensiveert en wordt gecultiveerd. Onder een dergelijk gesternte is een blijvende ontwikkeling en praktisering van een Social Innovation Approach geen overbodige luxe.

\section{Social Innovation Approach}




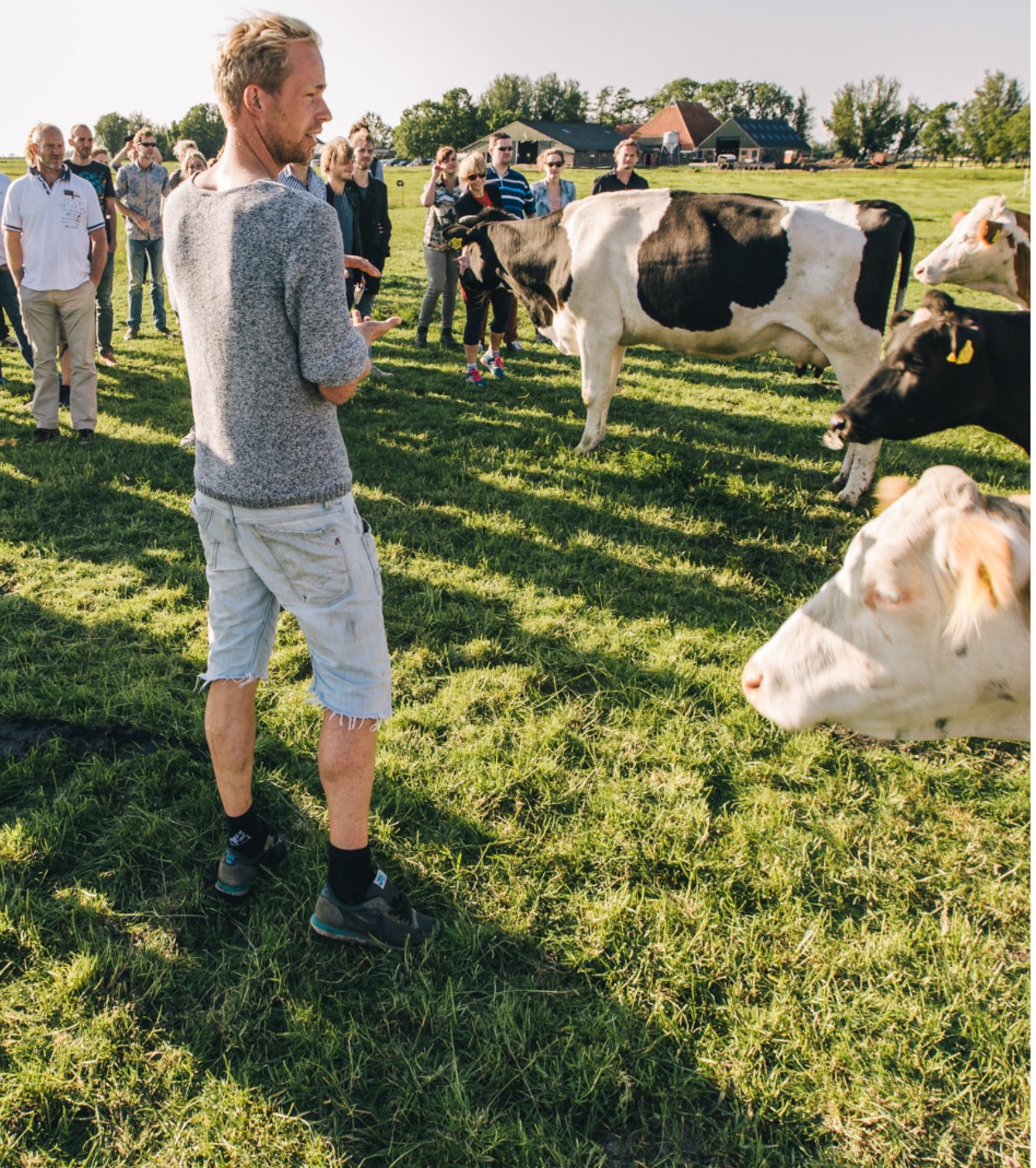

\section{Noten}

1. De resultaten zijn te vinden op www. wur.nl/nl/Onderzoek-Resultaten/Onderzoeksprojecten-LNV/Expertisegebieden/ Kennisbasis-onderzoek/KB-projecten-lopend-in-2018/Social-Innovation-for-Value-Creation.htm

2. R. Powers (2018). Tot in de hemel. Amsterdam: Uitgeverij Atlas Contact, 151.

3. Zie voor 'definitiekwesties' bijvoorbeeld: Dagevos, G. Walraven \& P.M. Karré (2018). Sociale innovatie in de praktijk: inleiding, i.h.b. 3-5. In: P.M. Karré, H. Dagevos \& G. Walraven (red.), Sociale innovatie in de praktijk: Zoeken naar nieuwe antwoorden op maatschappelijke vraagstukken. Assen: Uitgeverij schappelijke var Konink je H.K. Anheier \& G. Mildenberger (2019). Introduction: Social innovation -what is it and who makes it?, i.h.b. 17-19. In: H. K. Anheier, G. Krlev \& G. Mildenberger (eds.) Social innovation: Comparative perspectives. New York: Routledge, 3-35.

4. Voor wie geïnteresseerd is in de filosofische aspecten, wordt verwezen naar: F.W. Keulartz, M. Korthals, M. Schermer \& T.E. Swierstra (eds.) (2002). Pragmatist ethics for a technological culture. Dordrecht: Kluwer.

5. Zie: H. Dagevos (2018). Sociale innovatie: Sociologische traditie en voedseltransitie. In: P.M. Karré, H. Dagevos \& G. Walraven (red.), Sociale innovatie in de praktijk: Zoeken naar nieuwe antwoorden op maatschappelijke vraagstukken. Assen: Uitgeverij Koninklijke Van Gorcum, 11-25; R. During, J. BrouVan Gorcum, 11-25; R. During, J. Brou-
wers \& L. Klep (2017). Social innovation for value creation. Wageningen: Wageningen Environmental Research; M. Fougère, B. Segercrantz \& H. Seeck (2017). A critical reading of the European Union's social innovation poli novation po neoliberalsm. Organization R.P. van der Habe \& Lubalcaba (2016) Social innovation research: An emerging area of innovation studies? Research Policy, 45, 1923-1935; TSI Manifesto (2017). tsimanifesto.org/app/uploads/2017/12/Ma-

Foto: Hans Jellema (Kening fan 'e Greide)
nifesto-for-Transformative-Social-Innovation-v0.1-Oct-2017-1.pdf

6. B. Latour (2004). Why has critique run out of steam?: From matters of fact to matters of concern? Critical Inquiry, 30, 225-248.

7. Zie: $w$ ww.linkedin.com/feed/update/ urn:li:activity:6396632849155452928

8. De Italiaanse professor Ezio Manzini van de Poytechnische Universiteit van Milaan herformuleerde het migratieprobleem in een presentatie op 12-04-2016 in Siracusa als volgt: a) het gaat niet over migranten maar over mensen op de vlucht die een menselijke aanpak nodig hebben en geen overheidsproject willen zijn; b) het gat niet over helpen van migranten mat niet over helpen van migranten maar over samenwerken met mensen die een achtegrond, kennis en ervaring meenemen, c) het gaat niet over individuele successen, maar over waardecreatie in een community benadering.

9. Zie voor het verschil tussen SI en RRI hoofdstuk 2 (i.h.b. 21-29) van het Wageningse proefschrift Responsible innovation in industry: Learning from social entrepreneurship van Rob Lubberink (januari 2018). Zie in dit kader van een vergelijking tussen SI een RRI eveneens Enabling Wageningen University and Research to achieve its mission through Responsible Research and Innovation (juli 2018) van de Wageningse collega's David Ludwig, Philip Macnaghten en Auke Pols, dat tegelijkertijd zeer verschilt van opzet en uitwerking met ons SI-betoog als dat diverse punten worden aangekaart die er mee overeenstemmen dan wel in lijn liggen.

10. Zie: www.dekennisvannu.nl/site/artikel/ CO2-vastleggen-in-steen/6570 Zie: www. ad.n1/utrecht/86-jarige-biltenaar-heeft-oplossing-voor-het-co2-probleem-en-doet-melossing

aan-miljoenenprijsvraag a3f56dac/

Zie bijvoorbeeld het Nexus Netwerk als investering van de Engelse SER: www. thenexusnetwork.org

12. lemand zit al jaren met zijn gezin in de 
bijstand en wordt bezocht door talloze overheidsinstanties. Hij heeft grote schulden maar kan niet in de schuldsanering omdat een heel klein elementje van een schuld te maken heeft met een straf die hem door de rechter is opgelegd. Er lijkt geen uitweg te zijn en het gezin kost de staat veel meer dan 100.000 euro per jaar. Met het wegnemen van de kleine schuld opent het Instituut voor Publieke Waarden de weg naar de schuldsanering, en daarmee naar een betere toekomst voor het hele gezin.

13. Opvallend dat in de innovatietheorie zo weinig aandacht besteed wordt aan veranderen van binnenuit.

14. Zie: lists.riseup.net/directory/agriculture Ook social trade is interessant in dit verband, zie: www.socialtrade.n

15. journals.sagepub.com/doi/abs/10.1177/0 01258069411238601?journalCode=tdra

16. Zie hier voor het werk van The International Association for the Study of the Commons: www.iasc-commons.org

17. Het mag duidelijk zijn dat het evenzee belangrijk is om dit onderdeel van een Social Innovation Approach verder te brengen dat opdrachtgevers hierin mee worden genomen en het gesprek ove hun ideologie en idealen wordt aangegaan en expliciet(er) gemaakt.

18. Dit speelde in een Drents dorp Gasselternijveen, waarin de wethouder van de gemeente werd uitgelegd dat er vee mensen met een label leven op basis waarvan ze rechten ontlenen op steun van de gemeente, goed voor 100.000 euro per jaar, maar dat een collectief zorgcentrum dezelfde taken kon vervullen voor 30.000 euro. De wethouder ging hier in mee.

19. www.rtlnieuws.nl/gezondheid/nietzwanger-worden-dankzij-app-goed-planof-niet

20. Zie M. Nussbaum (2001). Oplevingen van het denken: Over menselijke emoties. Amsterdam: Ambo. Als voorbeeld kunnen we de discussie over de paarden in de Oostvaardersplassen noemen. Met veel emotie wordt gereageerd op paarden die mager zijn. Onder paardenliefhebbers bestaat veel kennis over de gezondheid en het gedrag van paarden. Door deze kennis te mobiliseren en te benutten in de monitoring van het te benuttenin de dierenwelzijn, zal het draagvlak voor de uitkomsten van onderzoek veel groter zijn.

21. Zie bijvoorbeeld het Connected Communities Programme: connected-communities.org

22. D.M. Bell \& K. Pahl (2018). Co-production: Towards a utopian approach. International Journal of Social Research Methodology, 21, 105-117.

23. Zie: www6.inra.fr/sciences-en-questions 24. Dit stuk is gebaseerd op een uitwisseling inzake citizen science tussen WUR en INRA. Zie ook: www.sciences-participatives.inra.com; www.sciences-participatives.com/en

25. Vergelijk de strategie voor systeeminnovatie van het Finance Innovation Lab, die werkt met intrapreneurs: financeinnovationlab.org/wp-content/ uploads/2015/04/FIL_SystemsChange-Web-Final.pdf Overigens geldt het pleidooi voor meer decentrale strategie-ontwikkeling ook voor de vier luisin die we in deze paragraaf aanstippen: die zouden alle vier kunnen worden opgepakt door een reflectiegroepje (van 'dwarsdenkers') waarvan de leden uit verschillende kennisgroepen gerekruteerd worden. Ze zouden het sociaal leren van de organisatie kunnen vormgeven. Het zal kunnen leiden tot de zo gewenste zal kunis or et het bijzonder tussen maatschappijwetenschap en technische kennis- en innovatieontwikkeling. Hun takenpakket zou ook kunnen omvatten een netwerk van intrapreneurs (werkzaam in grote organisaties in het domein van ontwikkelen, waarm en activisten te ontwikg contact hebben en die willen werk an een sociale innovatie agenda. 26. Zo houden volgens David Mosse ont- wikkelingsorganisaties vaak een positief verhaal over hun werk om geen investeerders af te chrikken: https: www.soas.ac.uk/staff/s

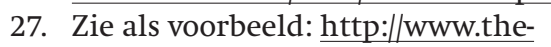
nexusnetwork.org/\#

28. In dit verband bepleit Martijntje Smit (2018: 7): "Het publiek - burgers, maa schappelijke organisaties - zal voluit als gelijkwaardige gesprekspartner mee moeten kunnen praten over wat echt zinvolle thema's zijn, waar onderzoek naar nodig is. Dat gesprek houdt niet op als het onderzoek gestart is. Ook tijdens het onderzoek dient is. partijen te blijven meedenken om zo nodig onderzoeksvragen bij te stellen. Zorg ook dat wetenschappers kunnen samenwerken met niet-kapitaalkrachtige partijen buiten de universiteit want dit is in het huidige systeem hee moeilijk. Aan onderzoeksprojecten zou je een 'klankbordgroep' kunnen toevoegen, waarin maatschappelijke organisaties zitten." - M. Smits (2018). Geef de universiteit terug aan de burger. Trouw, zaterdag 1 september, 4-7. 


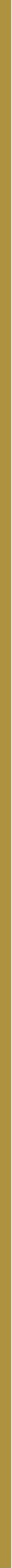

